\title{
Analisis Pengakuan dan Penyajian Lebih Bayar dan Kurang Bayar Dana Bagi Hasil Pada Laporan Keuangan BUN BA-999.05
}

\author{
Deni Herdiyana \\ deni.herdiyana@pknstan.ac.id \\ Politeknik Keuangan Negara STAN, BPPK-Kemenkeu
}

\begin{abstract}
This study aims to identify and ensure that the recognition, recording, summarizing and reporting of Overpayment and Underpayment of Profit Sharing Funds are in accordance with the provisions of Government Accounting Standards. The study was conducted using a descriptive approach, concluding that the recording, summarizing, and financial reporting of TKDD transactions were in accordance with the applicable accounting principles. This is indicated by the 2016-2018 BUN Financial Report getting an Unqualified Opinion from the BPK. The results of the study recommend that the DGT should be actively involved in facilitating the reconciliation of DBH data with the Directorate General of Treasury, the Directorate General of Taxes and the Directorate General of Customs and Excise, as well as the relevant technical ministries and the distribution of Profit Sharing Funds in the third and fourth quarters should be based on realization. Furthermore, it is necessary to conduct intensive and thorough socialization to all stakeholders so that the use of the Simponi application can be used optimally.
\end{abstract}

Keywords: Overpayment, Underpayment, Profit Sharing Funds, Government Accounting Standards.

\begin{abstract}
ABSTRAK
Kajian ini bertujuan untuk mengetahui dan memastikan bahwa pengakuan, pencatatan, pengikhtisaran dan pelaporan Lebih Bayar (LB) dan Kurang Bayar (KB) Dana Bagi Hasil sudah sesuai dengan ketentuan Standar Akuntansi Pemerintahan (SAP). Kajian dilakukan dengan pendekatan deskriptif menyimpulkan bahwa pencatatan, pengikhtisaran, dan pelaporan keuangan atas transaksi TKDD telah sesuai dengan prinsip-prinsip akuntansi yang berlaku. Hal tersebut diindikasikan dengan Laporan Keuangan BUN TA 2016-2018 mendapatkan opini Wajar Tanpa Pengecualian (WTP) dari BPK. Hasil kajian merekomendasikan bahwa DJPK sebaiknya terlibat secara aktif dalam memfasilitasi rekonsiliasi data DBH dengan Direktorat Jenderal Perbendaharaan, Direktorat Jenderal Pajak dan Direktorat Jenderal Bea dan Cukai, serta Kementerian Teknis terkait dan penyaluran Dana Bagi Hasil pada triwulan III dan IV sebaiknya berdasarkan realisasi. Lebih lanjut, perlu dilakukan sosialisasi intensif dan menyeluruh kepada semua stakeholder sehingga penggunaan aplikasi Simponi dapat digunakan secara optimal.
\end{abstract}

Kata Kunci: Lebih Bayar (LB), Kurang Bayar (KB), Dana Bagi Hasil, Standar Akuntansi Pemerintahan (SAP) 


\section{PENDAHULUAN}

Pengelolaan keuangan Negara Republik Indonesia telah mengalami perubahan yang besar salah satunya adalah perubahan dari segi pencatatan dan pelaporan keuangan atau yang biasa dikenal dengan akuntansi. Terkait dengan akuntansi pemerintah, secara keseluruhan Indonesia telah mengalami 3 (tiga) fase perkembangan dalam penerapan akuntansi pemerintahan.

\section{Fase I: Masa Pra Reformasi (Sebelum Tahun 2000)}

Menurut (Bastian, 2010), pengelolaan akuntansi sektor publik pada masa pra reformasi mengacu pada UU No. 5 Tahun 1974 tentang Pokok-Pokok Pemerintahan di Daerah yang diikuti dengan beberapa peraturan pelaksanaannya yaitu PP No. 5 Tahun 1975 tentang Pengurusan, Pertanggungjawaban dan Pengawasan Keuangan Daerah, PP No. 6 Tahun 1975 tentang penyusunan APBD, Pelaksanaan Tata Usaha Keuangan Daerah dan Penyusunan Perhitungan APBD (Republik Indonesia, 1975), Kepmendagri No. 900-099 Tahun 1980 tentang Manual Administrasi Keuangan Daerah (MAKUDA), Permendagri No. 2 Tahun 1994 tentang pelaksanaan APBD, UU No. 18 Tahun 1997 tentang Pajak dan Retribusi Daerah (Republik Indonesia, 1997), serta Kepmendagri No. 3 Tahun 1999 tentang bentuk dan susunan perhitungan APBD.

Sistem pencatatan pada akuntansi di sektor pemerintahan masih menggunakan single entry. Pencatatan transaksi keuangan dilakukan dengan mencatat satu kali, transaksi yang berakibat bertambahnya kas akan dicatat pada sisi penerimaan dan transaksi keuangan yang berakibat berkurangnya kas akan dicatat pada sisi pengeluaran (Tanjung, 2008). Dampak dari sistem pencatatan tersebut, pemerintah tidak memiliki catatan mengenai pos-pos neraca yaitu aset tetap, piutang, utang dan ekuitas dari suatu entitasnya.

\section{Fase II: Masa Reformasi (Tahun 2000-2004)}

Diawali dengan perubahan besar melalui terbitnya paket peraturan perundangperundangan yang berkaitan dengan perbaikan dalam pengelolaan keuangan negara, yaitu UU No. 22 Tahun 1999 tentang Pemerintahan Daerah dan UU No. 25 Tahun 1999 tentang Perimbangan Keuangan Pusat dan Daerah, UU No. 17 Tahun 2003 tentang Keuangan Negara dan UU No. 1 Tahun 2004 tentang Perbendaharaan Negara. Selain itu, ditetapkan juga UU No.15 Tahun 2004 tentang Pemeriksaan Pengelolaan dan Tangung Jawab Keuangan Negara. 
Sejalan dengan reformasi di bidang keuangan negara, pencatatan dan penyajian laporan keuangan pemerintah telah mengalami perbaikan yang semula dari basis single entry menjadi double entry. Sistem pencatatan double entry mengacu pada PP No. 105 Tahun 2000 tentang Pengelolaan dan Pertanggungjawaban Keuangan Daerah. Pengakuan belanja dan pendapatan pada dasarnya sama yaitu menggunakan basis kas, tetapi untuk kepentingan penyusunan neraca digunakan modified accrual basis, yang artinya belanja modal atau investasi dicatat sebagai aset di neraca.

\section{Fase III: Masa Modern (Tahun 2005 - Sekarang)}

Pada masa ini, entitas akuntansi dan pelaporan baik Pemerintah Pusat maupun Pemerintah Daerah menerapkan basis kas menuju akrual berdasarkan PP No. 24 Tahun 2005 tentang Sistem Akuntansi Pemerintahan. Penerapan basis kas menuju akrual, mengakui pendapatan-LRA pada saat terjadi transaksi aliran masuk ke Rekening Kas Umum Negara (RKUN) dan mengakui belanja-LRA pada saat terjadi transaksi aliran keluar RKUN dan tidak ada pengakuan transaksi akrual pada pendapatan dan beban. Mulai tahun 2015 setiap entitas akuntansi dan pelaporan sudah menerapkan basis akrual berdasarkan PP No.71 Tahun 2010. Seiring dengan perkembangan akuntansi pemerintah yang begitu pesat, Sistem Akuntansi Transfer ke Daerah (SATD) telah mengalami banyak perubahan diawali dengan PMK No. 120/PMK.05/2009, selanjutnya direvisi menjadi PMK No. 263/PMK.05/2014 yang kemudian direvisi kembali menjadi PMK No. 216/PMK.05/2016. Perubahan yang terakhir adalah PMK No.83/PMK.05/2018 tentang Sistem Akuntansi Transfer ke Daerah dan Dana Desa. Dalam rangka pelaksanaan Pengelolaan Transfer Ke Daerah dan Dana Desa (BUN BA999.05), Menteri Keuangan menetapkan DJPK sebagai PPA BUN Pengelolaan Transfer ke Daerah dan Dana Desa. Adapun di tahun 2015, Laporan Keuangan BUN BA-999.05 mengalami perubahan basis akuntansi yaitu dari basis Kas Menuju basis Akrual.

\section{TINJAUAN TEORI}

\section{Dana Bagi Hasil}

Dana Bagi Hasil (DBH) adalah dana yang dialokasikan dalam APBN kepada daerah berdasarkan angka persentase tertentu dari pendapatan negara untuk mendanai kebutuhan daerah dalam rangka pelaksanaan desentralisasi. DBH terdiri atas Pajak dan Sumber Daya Alam (SDA). DBH Pajak adalah bagian daerah yang berasal dari penerimaan Pajak Bumi dan Bangunan, Pajak Penghasilan Pasal 25 dan Pasal 29 
Wajib. Pajak Orang Pribadi Dalam Negeri dan Pajak Penghasilan Pasal 21, dan Cukai Hasil Tembakau.

Sedangkan DBH SDA adalah bagian daerah yang berasal dari penerimaan kehutanan, mineral dan batubara, perikanan, pertambangan minyak bumi, pertambangan gas bumi, dan pengusahaan panas bumi. DBH dialokasikan berdasarkan dua prinsip yaitu (1) prinsip by origin, dimana daerah penghasil penerimaan negara mendapatkan bagian (persentase) yang lebih besar dan daerah lainnya dalam satu provinsi mendapatkan bagian (persentase) berdasarkan pemerataan, (2) penyaluran DBH dilakukan berdasarkan prinsip by actual revenue, dimana besarnya DBH yang disalurkan kepada daerah, baik daerah penghasil maupun yang mendapat alokasi pemerataan didasarkan atas realisasi penyetoran Penerimaan Negara Pajak (PNP) dan Penerimaan Negara Bukan Pajak (PNBP) tahun anggaran berjalan.

\section{Akuntansi Kurang Bayar dan Lebih Bayar Dana Bagi HasilPP No. 71 Tahun 2010}

Bedasarkan PSAP No. 09 tentang Akuntansi Kewajiban, utang transfer adalah kewajiban suatu entitas pelaporan untuk melakukan pembayaran kepada entitas lain sebagai akibat ketentuan perundang-undangan dimana besaran nominalnya diakui dan dinilai sesuai dengan peraturan yang berlaku. Kewajiban transfer dikategorikan sebagai kewajiban jangka pendek karena realisasi pembayarannya dari RKUN ke RKUD dilakukan tidak lebih dari 12 (dua belas) bulan. Sedangkan definisi Akuntansi Piutang berdasarkan PSAP No. 01 (Penyajian Laporan Keuangan) adalah hak suatu entitas pelaporan untuk menerima pembayaran dari entitas pelaporan lain sebagai akibat peraturan perundang-undangan.

\section{PMK No. 263/PMK.05/2014}

\section{a. Piutang Pihak Ketiga}

Berdasarkan Pasal 7 ayat (1) dan (2) PMK No. 263/PMK.05/2014, Piutang yang timbul atas pelaksanaan Transfer ke Daerah dan Dana Desa diakui pada saat dana Transfer ke Daerah dan Dana Desa yang dibayarkan oleh Pemerintah Pusat melebihi jumlah yang menjadi hak Pemerintah Daerah pada tahun anggaran yang bersangkutan dan diukur sebesar nilai nominal sesuai dengan Peraturan MenKeu mengenai lebih bayar transfer.

b. Piutang Diestimasi

Mengacu pada Pasal 7 ayat (3) dan (4) PMK No. 263/PMK.05/2013, Piutang Diestimasi diakui pada saat bagian pendapatan yang telah diterima rekening kas negara 
lebihkecil dari yang telah dibagihasilkan seluruhnya namunbelum diketahui jumlah hak negara yang harus dikembalikan dari masing-masing daerah penerima berdasarkan hasil perhitungan dan rekonsiliasi yang diukur sebesar nilai nominal sesuai dengan hasil perhitungan dan rekonsiliasi.

c. Kewajiban Pihak Ketiga

Pasal 11 ayat (1) dan (2) PMK No. 263/PMK.05/2013 menyatakan bahwa Utang Transfer ke Daerah dan Dana Desa diakui pada saatditetapkannya Peraturan Menteri Keuangan mengenaikurang bayar transfer dan diukur sebesar nilai nominal sesuaidengan Peraturan Menteri Keuangan mengenai kurangbayar transfer.

d. Kewajiban Diestimasi

Kewajiban Transfer Dana Bagi Hasil (DBH) Diestimasidiakui pada saat bagian pendapatan yang telah diterimarekening kas negara belum dibagihasilkan seluruhnyakarena belum diketahui jumlah hak masing-masing daerahpenerima berdasarkan hasil perhitungan dan rekonsiliasi serta diukur sebesar nilai nominal sesuai denganhasil perhitungan dan rekonsiliasi.

\section{PMK No. 216 Tahun 2016}

a. Pengakuan Piutang

Berdasarkan Pasal 7 ayat (1) PMK No. 216 Tahun 2016, Piutang Transfer ke Daerah dan Dana Desa diakui pada saat dana Transfer ke Daerah dan Dana Desa yang disalurkan oleh Pemerintah Pusat melebihi jumlah yang menjadi hak Pemerintah Daerah pada tahun anggaran yang bersangkutan dan telah ditetapkan sebagai piutang transfer ke daerah dan dana desa berdasarkan dokumen penetapan lebih bayar dan/ atau lebih bayar sesuai Peraturan Menteri Keuangan mengenai transfer ke daerah dan dana desa, dalam hal ini adalah PMK No. 187/PMK.07/2016 tentang Perubahan atas Peraturan Menteri Keuangan No. 48/PMK.07 /2016 tentang Pengelolaan Transfer Ke Daerah Dan Dana Desa yang telah diubah dengan PMK No. 50/PMK.07/2017.

b. Pengakuan Kewajiban

Berdasarkan Pasal 10 ayat (1) PMK No.216 Tahun 2016, Utang Transfer ke Daerah dan Dana Desa diakui pada saat dana Transfer ke Daerah dan Dana Desa yang disalurkan oleh Pemerintah Pusat kurang jumlah yang menjadi hak Pemerintah Daerah pada tahun anggaran yang bersangkutan dan telah ditetapkan sebagai Utang Transfer ke Daerah dan Dana Desa berdasarkan dokumen penetapan kurang salur dan/atau kurang 
bayar sesuai PMK mengenai transfer ke daerah dan dana desa. Utang Transfer ke Daerah dan Dana Desa diukur sebesar nilai nominal berdasarkan dokumen penetapan kurang salur dan/atau kurang bayar sesuai PMK mengenai transfer ke daerah dan dana desa.

\section{PMK No. 83/PMK.07/2018}

PMK ini mengatur beban dan realisasi transfer ke daerah dan dana desa, piutang transfer ke daerah dan dana desa, utang transfer ke daerah dan dana desa, dan transaksi transitoris transfer ke daerah dan dana desa. Transaksi transitoris terkait transfer ke daerah dan dana desa merupakan hal baru yang dibahas pada peraturan ini yang sebelumnya belum ada pembahasan pada peraturan-peraturan sebelumnya. Proses akuntansi piutang dan utang transfer ke daerah dan dana desa mencakup hal-hal sebagai berikut: 1) Pengakuan, pengukuran dan penyajian baik piutang maupun utang TKDD; 2) Penyelesaian piutang/utang TKDD; 3) Pengakuan, pengukuran dan penyajian baik piutang maupun utang TKDD diestimasi; 4) Penyelesaian piutang/utang TKDD diestimasi; 5) Pengakuan, pengukuran dan penyajian piutang transfer pada UAKPA BUN jenis transfer yang berbeda; 6) Penyelesaian piutang transfer pada UAKPA BUN jenis transfer yang berbeda; 7) Koreksi piutang/utang TKDD dan piutang/utang TKDD diestimasi.

\section{METODE PENELITIAN}

Metode penelitian yang digunakan atas penyajian Lebih Bayar dan Kurang Bayar DBH pada Laporan Keuangan BUN BA-999.05 adalah melalui desk study dengan pendekatanan alisis deskriptif kualitatif yang terdiri dari:

\section{Analisis kualitatif atas data pada LKTD}

Data kurang bayar dan lebih bayar Dana Bagi Hasil (DBH) diperoleh melalui pengumpulan data dari buku LKTD yang telah diaudit oleh BPK, kemudian dilakukan analisis terhadap pengakuan, pencatatan, pengklasifikasian, pengikhtisaran dan pelaporan atas data kurang bayar dan lebih bayar DBH dari tahun 2008 sampai dengan tahun 2016.

\section{Review atas Peraturan terkait SAP}

Dalam melakukan penelitian atas Lebih Bayar dan Kurang Bayar DBH yang mencakup DBH Pajak dan DBH Sumber Daya Alam, penulis mengacu pada PP 71 Tahun 2010 tentang Standar Akuntansi Pemerintahan, PMK No. 216 Tahun 2016 tentang Standar 
Akuntansi Transfer ke Daerah (SATD) yang merupakan revisi dari PMK No. 263/PMK.05/2014, serta PMK No. 123 Tahun 2017 yang merupakan revisi dari PMK No. 50 Tahun 2017 tentang Pengelolaan Transfer ke Daerah dan Dana Desa.

\section{HASIL DAN PEMBAHASAN}

\section{Analisis kualitatif atas data pada LKTD}

Grafik yang tercantum di bawah ini merupakan data history mengenai perkembangan pengakuan dan pencatatan Piutang dan Kewajiban selama sembilan tahun terakhir, dimana masing-masing dari pos Piutang dan Kewajiban tersebut mengalami fluktuatif untuk periode TA 2008 sampai dengan TA 2016.

Grafik 1 Tren Perkembangan Piutang dan Kewajiban TA 2008-2016

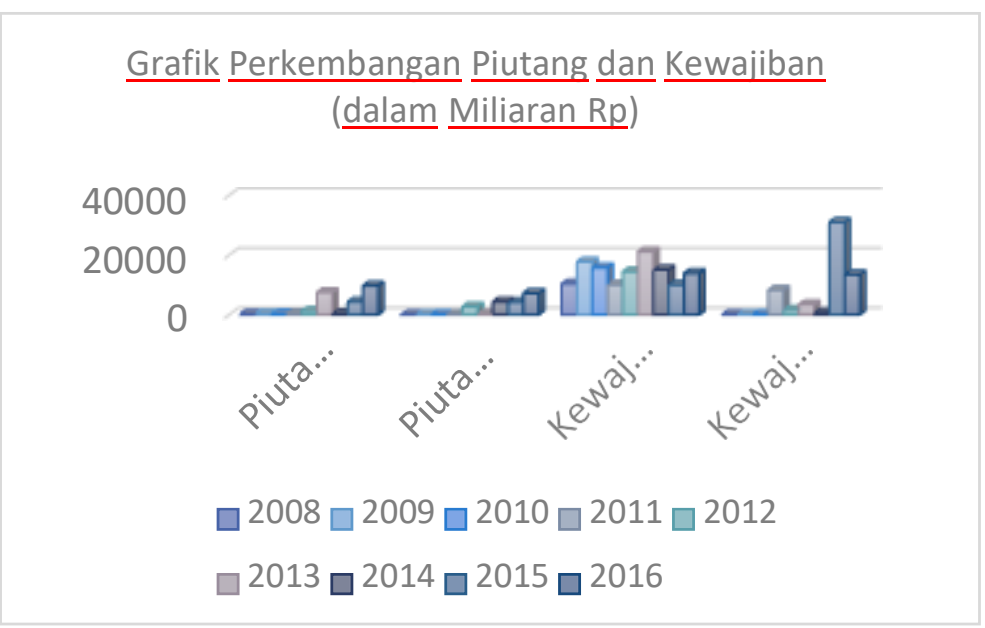

a. Piutang TKD

Piutang TKD atau biasa disebut Piutang Pihak Ketiga merupakan piutang yang diakui oleh Pemerintah Pusat atas kelebihan salur kepada Pemerintah Daerah dimana Pemda provinsi/kabupaten/kota dan besaran nominal kewajiban dari masing-masing daerah tersebut sudah dapat teridentifikasi. Untuk periode 2008- 2016, besaran Piutang TKD tersebut mengalami perubahan secara fluktuatif yaitu:

Grafik 2 Perkembangan Piutang TKD TA 2008-2016

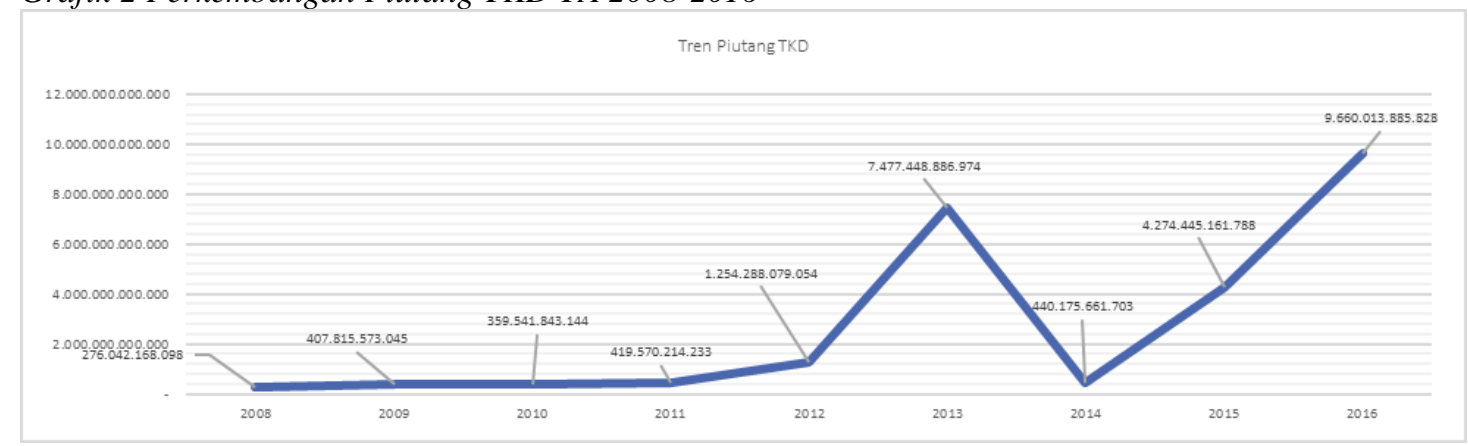


Berdasarkan gambar grafik di atas, terlihat bahwa Piutang TKD pada tahun 2008 sebesar Rp276 miliar kemudian mengalami fluktuasi yang tidak terlalu besar sampai dengan tahun 2011 sebesar Rp419,57 miliar, kemudian mengalami kenaikan pada tahun 2012 secara signifikan menjadi sebesar Rp1.254,29 miliar dan naik lagi menjadi Rp7.477,45 miliar pada tahun 2013, selanjutnya pada tahun 2014 turun menjadi Rp440,18 miliar dan kemudian secara berturut-turut naik menjadi Rp4.274,4 miliar pada tahun 2015, dan naik lagi pada tahun 2016 menjadi Rp9.660 miliar. Piutang TKDD TA 2016 sebesar Rp9.568,5 miliar terdiri dari Piutang LB DBH periode lampau sebesar Rp 1.169,47 miliar dan Piutang LB DBH tahun berjalan sebesar Rp 8.399,05 miliar. Terkait Piutang LB DBH periode lampau terdapat penyesuaian besaran nominal, hal tersebut diakibatkan adanya pelunasan atas piutang tersebut melalui mekanisme pemotongan SPM atas realisasi transfer ke daerah TA 2016 yang didasarkan pada Peraturan Direktur Jenderal Perimbangan Keuangan.

b. Piutang TKDD Lainnya

Besaran nominal Piutang TKDD Lainnya dihitung berdasarkan selisih antara nilai penerimaan pada LKPP Audited dengan realisasi penyaluran tahun berjalan. Piutang TKDD Lainnya pertama kali muncul pada Laporan Keuangan BUN BA- 999.05 TA 2012 sebesar Rp2,66 triliun, kemudian turun menjadi Rp246,5 miliar di tahun 2013, selanjutnya mengalami kenaikan yang signifikan menjadi Rp4,29 triliun di tahun 2014 dan bertahan di kisaran Rp4,21 triliun pada tahun 2015, kemudian di tahun 2016 mengalami kenaikan yang signifikan menjadi Rp7,21 triliun.

Grafik 3 Perkembangan Piutang TKDD Lainnya TA 2012-2016

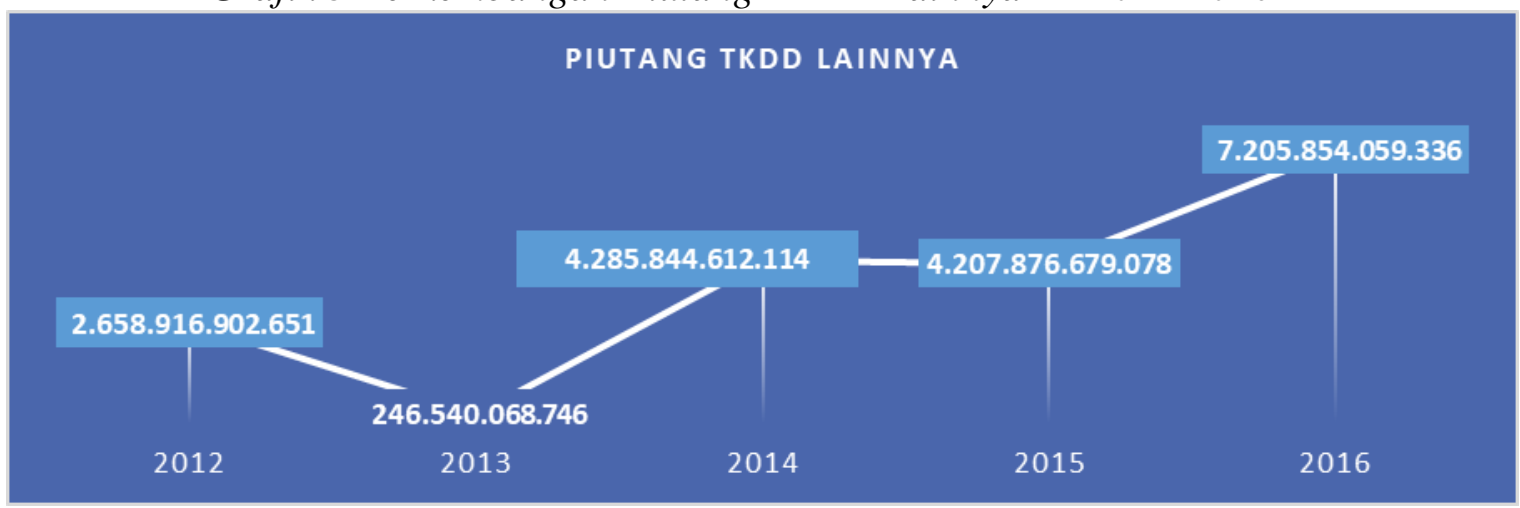

Berdasarkan LKTD Audited TA 2016, kenaikan Piutang TKDD Lainnya di TA 2016 menjadi sebesar Rp7,21 triliun dikarenakan oleh beberapa faktor, diantaranya adalah sebagai berikut:

1. Piutang TKDD Lainnya yang terdiri dari PNBP dan Pajak yang seharusnya 
dibagihasilkan berdasarkan pada TA 2016, berdasarkan pada selisih antara data penerimaan tahun berjalan dengan realisasi penyaluran DBH dan kurang salur DBH TW IV setelah disesuaikan (set off) dengan utang diestimasi dengan jenis DBH yang sama sebesar Rp7.043.590.804.308 yang terdiri dari DBH SDA sebesar Rp (5.780.648.380.134,-) dan DBH Pajak sebesar Rp (1.262.942.424.175,-) yang merupakan selisih antara pendapatan yang seharusnya dibagihasilkan dengan realisasi penyaluran DBH dan kurang salur DBH TW IV sebesar Rp11.525.752.044.560 setelah disesuaikan (set off) dengan utang diestimasi berdasarkan Nota Dinas usulan koreksi ND-134/PK.2/2017 (yang diterbitkan oleh subdit teknis).

2. Piutang atas Lebih bayar DBH PBB TA 2013 yang disajikan dalam Piutang diestimasi pada LKTD TA 2015 namun belum diperhitungkan dalam PMK 162/2016 sebesar Rp162.263.255.028.

Berdasarkan pengamatan dan analisa penulis, ND dan surat untuk pengakuan Piutang TKDD Lainnya sebaiknya tidak dijadikan sebagai dokumen sumber untuk pengakuan dan pencatatan Piutang TKDD Lainnya karena sebagai bentuk kehati-hatian dan dari segi peraturan tidak kuat dan tidak mengikat, namun sebaiknya menggunakan peraturan yang lebih tinggi dan mengikat seperti Perdirjen dan PMK.

c. Kewajiban TKDD

Grafik 4 Perkembangan Kewajiban TKD TA 2008-2016

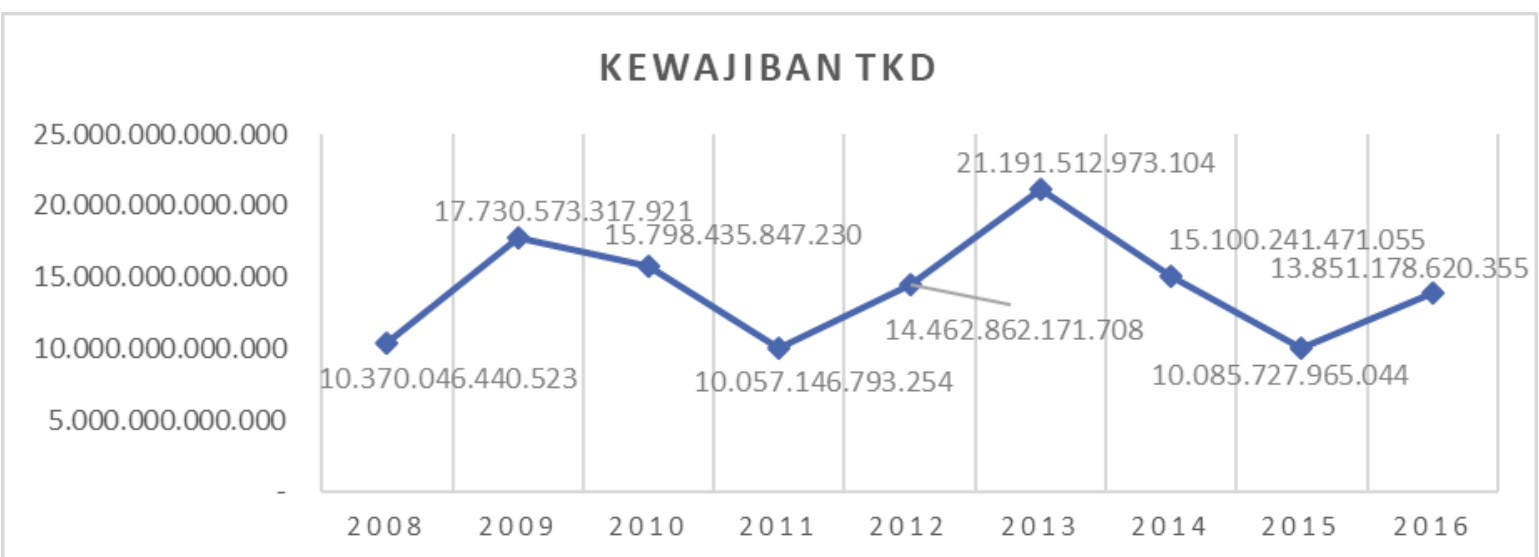

Kewajiban TKD dari tahun 2008 sampai dengan 2016 mengalami fluktuatif, pada tahun 2008 terdapat pengakuan kewajiban sebesar Rp10,37 triliun kemudian naik menjadi Rp17,73 triliun selanjutnya berangsur-angsur turun sampai Rp10,06 triliun di tahun 2011. Kemudian mengalami kenaikan secara signifikan di tahun 2012 dan 2013 masing-masing sebesar Rp14,46 triliun dan Rp21,19 triliun, selanjutnya berkurang secara berangsur-angsur sampai dengan Rp10,09 triliun, tetapi di tahun 2016 
mengalamikenaikan menjadi Rp13,85 triliun.

Terdapat kenaikan yang signifikan untuk Kewajiban TKD antara periode 2011 sampai dengan periode 2013, dimana kewajiban tersebut pada tahun 2011 sebesar Rp10,06 triliun kemudian naik menjadi Rp14,46 triliun dan puncaknya pada tahun 2013 naik lagi menjadi sebesar Rp21,19 triliun. Adapun rincian kewajiban di tahun 2013 tersebut terdiri dari Kurang Salur Dana Tunjangan Profesi Guru PNSD sebesar Rp4.310,75 miliar, kurang bayar Dana Bagi Hasil Pajak sebesar Rp1.486,71 miliar, kurang bayar Dana Bagi Hasil Cukai Hasil Tembakau sebesar Rp124,17 miliar dan Kurang Bayar Dana Bagi Hasil Sumber Daya Alam sebesar Rp15.269,97 miliar dimana DBH SDA merupakan angka terbesar dibandingkan dengan jenis kurang bayar lainnya.

Pengakuan Kurang Bayar TKD TA 2013 tersebut berdasarkan pada PMK No. 47/PMK07/2014 tentang Alokasi Kurang Bayar Dana Bagi Hasil Sumber Daya Alam Kehutanan TA 2006 sampai dengan TA 2012. Adapun nilai kurang bayar DBH Migas, kurang bayar DBH Panas Bumi, kurang Bayar DBH Kehutanan, dan kurang bayar DBH Perikanan untuk TA 2013 diakui dan dicatat berdasarkan Nota Dinas Kasubdit DBH SDA No.:ND-82/PK22/2014 tentang Penyampaian Bahan Penyusunan LKTD Audited TA 2013, sedangkan pencatatan kurang bayar DBH Minyak Bumi TA 2012 sebesar Rp357,46 miliar dilakukan sebelumnya dalam LKTD Audited TA 2012 dan belum tersalurkan ke daerah berdasarkan Nota Dinas Kasubdit DBH SDA No.:ND- 43/PK22/2013 tertanggal 14 Februari 2013.

Terdapat penurunan kewajiban TKD TA 2015 menjadi Rp10,09 triliun yang sebelumnya Rp15,1 triliun, hal tersebut dikarenakan adanya kewajiban yang sudah dilunasi sebesar Rp11,94 triliun. Selain itu, terdapat Kewajiban TKD yang baru diakui dan dicatat pada tahun tersebut berdasarkan PMK No.259/PMK.07/2015 dan PMK No.4/PMK.07/2016 dan juga adanya penambahan dari reklasifikasi kewajiban diestimasi dengan terbitnya PMK Kurang Bayar. Selanjutnya di tahun 2016, terdapat penyesuaian Kewajiban TKD menjadi sebesar Rp13,85 triliun dikarenakan terdapat pembayaran kewajiban periode lampau melalui realisasi transfer dan timbulnya kewajiban tahun berjalan yang baru muncul di TA 2016 dengan terbitnya PMK 162 Tahun 2016.

Menurut catatan penulis, masih terdapat penggunaan nota dinas Kasubdit dari subdit teknis dalam rangka untuk menyesuaikan pengakuan kewajiban. Penulis 
berpendapat bahwa seyogyanya pengakuan dan pencatatan kewajiban TKD tidak menggunakan nota dinas melainkan menggunakan dokumen sumber yang baku dan mengikat secara hukum seperti Perdirjen dan PMK. Sehingga pengakuan kurang bayar akan lebih valid dan akuntabel dari sisi compliance terhadap peraturan SAP.

d. Kewajiban TKDD Lainnya

Kewajiban TKDD Lainnya merupakan kewajiban diestimasi dimana besaran angkanya diperoleh dari selisih antara persentase penerimaan bagi daerah berdasarkan LKPP Audited dengan realisasi transfer tahun berjalan dimana hak dari masing-masing daerah provinsi/kabupaten/kota belum dapat ditentukan karena masih bersifat agregat.

Grafik 5 Perkembangan Kewajiban TKD Diestimasi TA 2010-2016

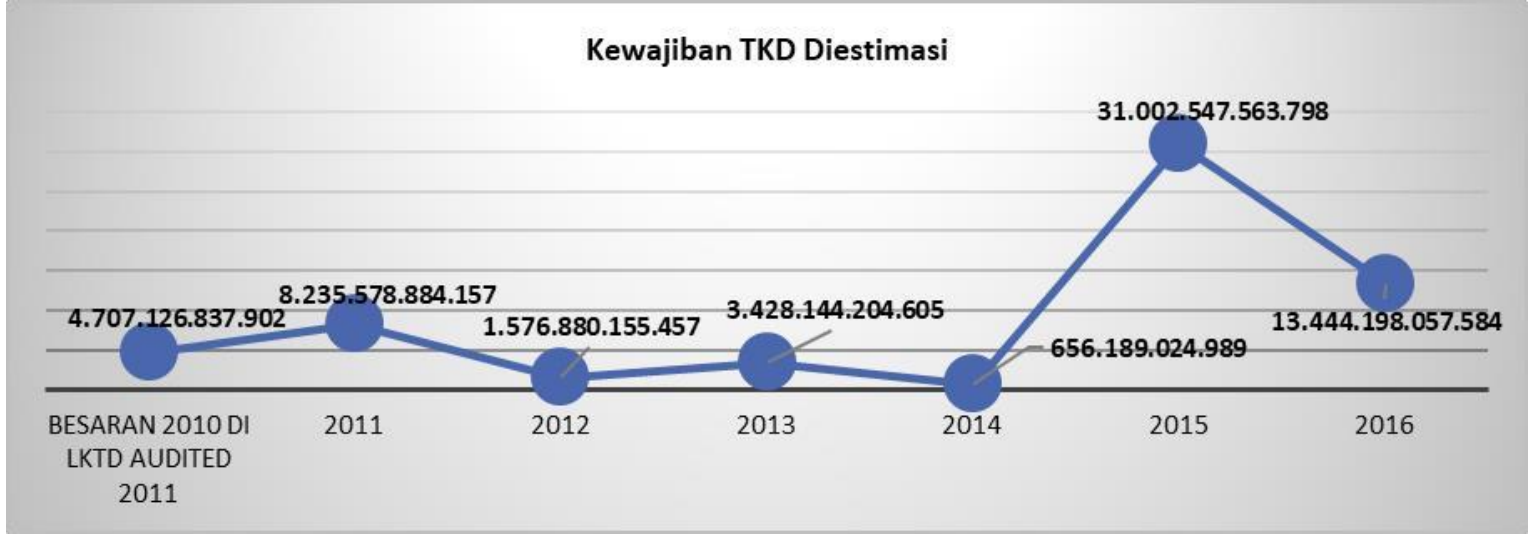

Berdasarkan gambar grafik di atas, terlihat bahwa kewajiban TKD Diestimasi mulai diakui dan dicatat di periode 2010 pada LKTD Audited TA 2011 sebesar Rp4,71 triliun, tetapi angka tersebut belum diakui di LKTD Audited TA 2010. Tahun selanjutnya terdapat fluktuatif yang tidak terlalu signifikan antara tahun 2010 sampai dengan 2014, namun demikian di tahun 2015 terdapat kenaikan yang sangat signifikan yaitu dari besaran Rp656,19 miliar pada tahun 2014 menjadi Rp31 triliun pada tahun 2015. Besaran angka Rp31 triliun tersebut berasal dari nilai kewajiban TKD Diestimasi yang baru diakui untuk DBH Pajak dan SDA berdasarkan pada Nota Dinas Kasubdit DBH Pajak No. ND-237/PK.2.1/2015 tanggal 29 Juni 2015 dan angka tahun sebelumnya berdasarkan LHP BPK TA 2014.

Adapun di tahun 2016, terdapat penurunan yang cukup signifikan dari Rp31 triliun menjadi Rp13,44 triliun. Angka Rp13,44 triliun tersebut merupakan selisih antara pendapatan yang seharusnya dibagihasilkan dengan realisasi penyaluran DBH dan kurang salur DBH TW IV setelah di-set off dengan piutang diestimasi menjadi sebesar Rp12.563.708.355.676,- (ND-134/PK.2/2017 yang diterbitkan oleh subdit teknis) 
sebagaimana tercantum pada table 9. Selain itu, terdapat jurnal koreksi mengenai penyajian kembali atas kewajiban kurang bayar DBH SDA Kehutanan TA 2012 dan 2013 yang disajikan dalam Utang Estimasi LKTD TA 2015 namun belum diperhitungkan dalam PMK No. 162 Tahun 2016 sebesar Rp72.582.964.434 kemudian ditambah pula dengan koreksi pengakuan penerimaan DBH SDA TA 2015 yang belum diperhitungkan untuk dibagihasilkan yang merupakan selisih nilai PNBP berdasarkan LKPP audited 2015 dengan PNBP yang telah diperhitungkan untuk dibagihasilkan sebesar Rp807.906.737.475,--.

\section{Review atas Peraturan terkait SAP}

a. Piutang Pihak Ketiga

Pengakuan piutang pihak ketiga periode TA 2012-2014 berdasarkan PMK No. 120/PMK.05/2009 dimana pengungkapan dan pengakuan piutang mengacu pada prinsip substance over form. Oleh karena itu, pencatatan piutang tersebut lebih ditekankan pada kertas kerja hasil rekonsiliasi dengan kementerian/lembaga teknis terkait dimana hak negara dari masing-masing daerah penerima telah teridentifikasi tanpa menunggu terbitnya PMK/Perdirjen mengenai Lebih bayar DBH Sumber Daya Alam. Sedangkan mulai TA 2015 dengan menerapkan basis akrual, pengakuan piutang DBH SDA berdasarkan pada PMK No. 263/PMK.05/2014 sebagai pengganti dari PMK No. 120/PMK.05/2009 yang menegaskan bahwa piutang pihak ketiga diakui pada saat terbitnya PMK/Perdirjen mengenai Lebih bayar walaupun sebelumnya telah diketahui hak negara dari masing-masing daerah penerima melalui rekonsiliasi dengan kementerian/lembaga teknis terkait.

b. Piutang Diestimasi

Nilai Piutang diestimasi DBH SDA diperoleh dari penghitungan selisih kurang antara besaran nilai DBH Sumber Daya Alam yang dihitung berdasarkan data prognosa/realisasi PNBP yang dibagihasilkan dengan realisasi transfer DBH SDA yang telah disalurkan sampai dengan triwulan IV, nilai tersebut diperoleh dari rekonsiliasi antara DJPK dengan kementerian/lembaga teknis terkait sebelum ditetapkan dengan PMK/Perdirjen mengenai Lebih bayar DBH Sumber Daya Alam.

c. Kurang Bayar Pihak Ketiga

Sebelum menerapkan basis akrual yaitu periode TA 2012-2014, pengakuan Kurang Bayar Pihak Ketiga DBH SDA mengacu kepada PMK No. 120/PMK.07/2009 
dimana pengakuan nilai kurang bayar tersebut mengacu pada prinsip substance over form yaitu nilai tersebut diakui dan dicatat berdasarkan pada kertas kerja hasil rekonsiliasi dimana besaran hak dari masing-masing daerah penerima telah teridentifikasi dengan andal tanpa menunggu penetapan peraturan mengenai alokasi kurang bayar. Sedangkan mulai TA 2015 setelah penerapan basis akrual, pengakuan danpencatatan kurang bayar DBH SDA mengacu pada PMK No. 263/PMK.05/2014.

Salah satu penyebab lamanya periode pelunasan untuk pembayaran kewajiban sebelum tahun 2015, dikarenakan pengakuan kewajiban tersebut dilakukan sebelum ditetapkannya PMK sebagai dasar untuk pengalokasian pada APBN. Sedangkan penetapan PMK Kurang Bayar tersebut memerlukan waktu yang lama. Hal ini disebabkan menunggu penetapan LKPP Audited untuk menghitung selisih antara penerimaan PNBP pada SAKUN yang akan dibagihasilkan dengan alokasi DBH SDA yang telah ditransfer untuk periode yang sama. Kemudian besaran alokasi kurang bayar tersebut masuk ke dalam APBN yang selanjutnya ditetapkan dengan Peraturan Presiden tentang alokasi transfer. Tahap berikutnya adalah penetapan SKPRTD sebagai dasar pembuatan SPP dan SPM pada Subdit Pelaksanaan Transfer sebelum dikirim ke KPPN. Jakarta II selaku SAKUN sebagai syarat untuk penerbitan SP2D untuk mentransfer kurang bayar DBH SDA dari RKUN ke RKUD.

d. Kurang Bayar Diestimasi

Pengakuan dan pencatatan kewajiban diestimasi sebelum TA 2015 adalah dihitung berdasarkan selisih antara porsi bagi hasil penerimaan PNBP yang masuk ke RKUN dengan realisasi transfer sampai dengan triwulan IV, angka tersebut masih bersifat akumulatif dimana masing-masing daerah penerima belum dapat diidentifikasi. Sedangkan mulai TA 2015, kewajiban diestimasi diakui pada saat peraturan mengenai alokasi kurang bayar belum ditetapkan tetapi besaran angkanya sudah diketahui yaitu melalui rekonsiliasi dengan kementerian/lembaga teknis terkait apakah hak masing- masing daerah provinsi/kabupaten/kota sudah teridentifikasi atau belum. Penyelesaian KB Diestimasi yang berlarut-larut salah satunya disebabkan sulitnya untuk mengidentifikasi hak dari masing-masing daerah kabupaten/kota. Selain itu, aplikasi simponi belum digunakan secara optimal sehingga belum bisa membantu untuk mengidentifikasi besaran hak dari masing-masing daerah penghasil PNBP. 


\section{KESIMPULAN}

Salah satu yang menjadi sorotan pemeriksaan BPK adalah akun-akun yang bersifat akrual yaitu Kurang Bayar dan Lebih Bayar DBH SDA dan Pajak. Hal ini dikarenakan pengakuan dan pencatatan tersebut memerlukan effort lebih besar dalam hal penyajian laporan keuangan melalui proses rekonsiliasi data antara penyaji laporan keuangan dengan unit-unit teknis. Selanjutnya ditindaklanjuti dengan verifikasi data dan memerlukan manual adjustment pada aplikasi SPAN. Terkait dengan penelitian ini, penulis menemukan beberapa temuan sebagai berikut: 1) Terdapat beberapa dokumen sumber dalam pengakuan dan pencatatan kurang bayar dan lebih bayar DBH masih menggunakan nota dinas dan kertas kerja, sehingga dokumen tersebut tidak kuat dan tidak mengikat secara legalitas. 2) Terdapat angka piutang dan kewajiban TA 2010 yang besarannya disajikan berbeda antara di face neraca LKTD TA 2010 Audited dengan LKTD TA 2011 Audited.

\section{SARAN}

1. DJPK seyogyanya terlibat secara aktif dalam memfasilitasi rekonsiliasi data DBH melalui rapat koordinasi dengan Direktorat Jenderal Perbendaharaan, Direktorat Jenderal Pajak, Dirjen Bea dan Cukai, serta Kementerian Teknis terkait.

2. Untuk mengurangi alokasi lebih bayar maupun kurang bayar pada tiap daerah, sebaiknya penyaluran DBH triwulan III dan IV berdasarkan realisasi.

3. Perlu dilakukan sosialisasi menyeluruh dan intensif kepada semua stakeholders terkait penggunaan aplikasi Simponi.

4. Pengakuan kurang bayar dan lebih bayar yang belum firm sebaiknya tidak diakui dan dicatat pada laporan keuangan tetapi menunggu penetapan peraturan.

\section{DAFTAR PUSTAKA}

Bastian, I. (2010). Akuntansi Sektor Publik Suatu Pengantar Edisi Ketiga. Jakarta, DKI Jakarta, Indonesia: Penerbit Erlangga.

Republik Indonesia, Peraturan Menteri Keuangan Nomor 83 Tahun 2018 tentang Sistem Akuntansi dan Pelaporan Keuangan Transfer ke Daerah dan Dana Desa.

Republik Indonesia, Keputusan Menteri Dalam Negeri Nomor 900-099 Tahun 1980 tentang Manual Administrasi Keuangan Daerah (MAKUDA).

Republik Indonesia, Peraturan Menteri Dalam Negeri Nomor 2 Tahun 1994 tentangpelaksanaan Anggaran Pendapatan dan Belanja Daerah.

Republik Indonesia, Keputusan Menteri Dalam Negeri Nomor 3 Tahun 1999 
tentang bentuk dan susunan perhitungan Anggaran Pendapatan dan Belanja Daerah.

Republik Indonesia, Peraturan Menteri Keuangan Nomor 120/PMK.05/2009 tentang Sistem Akuntansi dan Pelaporan Transfer ke Daerah.

Republik Indonesia, Peraturan Menteri Keuangan Nomor 213/PMK.05/2013 tentang Sistem Akuntansi dan Pelaporan Keuangan Pemerintah Pusat (SAPP).

Republik Indonesia, Peraturan Menteri Keuangan Nomor 263/PMK.05/2014 tentang Sistem Akuntansi dan Pelaporan Keuangan Transfer Ke Daerah dan Dana Desa.

Republik Indonesia, Peraturan Menteri Keuangan Nomor 216/PMK.05/2016 tentang Sistem Akuntansi dan Pelaporan Keuangan Transfer ke Daerah dan Dana Desa.

Republik Indonesia, Undang-Undang Nomor 5 Tahun 1974 tentang Pokok-Pokok Pemerintahan di Daerah.

Republik Indonesia, Peraturan Pemerintah Nomor 5 Tahun 1975 tentang Pengurusan,Pertanggungjawaban dan Pengawasan Keuangan Daerah.

Republik Indonesia, Peraturan Pemerintah Nomor 6 Tahun 1975 tentang penyusunan Anggaran Pendapatan dan Belanja Daerah.

Republik Indonesia, Undang-Undang Nomor 18 Tahun 1997 tentang Pajak dan Retribusi Daerah.

Republik Indonesia, Undang- Undang No. 22 Tahun 1999 tentang Pemerintahan Daerah.

Republik Indonesia, Undang- Undang No. 25 Tahun 1999 tentang Perimbangan Keuangan Pusat dan Daerah

Republik Indonesia, Peraturan Pemerintah Nomor 105 Tahun 2000 tentang Pengelolaandan Pertanggungjawaban Keuangan Daerah.

Republik Indonesia, Undang- Undang Nomor 17 Tahun 2003 tentang Keuangan Negara.

Republik Indonesia, Undang- Undang Nomor 1 Tahun 2004 tentang Perbendaharaan Negara.

Republik Indonesia, Undang- Undang Nomor 15 Tahun 2004 tentang Pemeriksaan Pengelolaan dan Tangung Jawab Keuangan Negara.

Republik Indonesia, Peraturan Pemerintah Nomor 24 Tahun 2005 tentang Sistem Akuntansi Pemerintahan.

Republik Indonesia, Undang- Undang Nomor 15 Tahun 2006 tentang Badan PemeriksaKeuangan.

Republik Indonesia, Peraturan Pemerintah Nomor 71 Tahun 2010 tentang Standar Akuntansi Pemerintahan.

Tanjung, A. H. (2008). Akuntansi Pemerintahan Daerah \& Konsep Aplikasi (SesuaiStandar Akuntansi Pemerintahan). Bandung: Alfabeta. 